\title{
Paideusis
}

\section{Reductionism in Education}

\section{R. T. Allen}

Volume 5, Number 1, 1991

URI: https://id.erudit.org/iderudit/1073354ar

DOI: https://doi.org/10.7202/1073354ar

See table of contents

Publisher(s)

Canadian Philosophy of Education Society

ISSN

0838-4517 (print)

1916-0348 (digital)

Explore this journal

Cite this article

Allen, R. (1991). Reductionism in Education. Paideusis, 5(1), 20-35.

https://doi.org/10.7202/1073354ar

This document is protected by copyright law. Use of the services of Erudit (including reproduction) is subject to its terms and conditions, which can be viewed online.

https://apropos.erudit.org/en/users/policy-on-use/ 


\section{Reductionism in Education}

\section{R.T. Allen, Loughborough \\ Leicestershire, England}

\section{Reductionism as a Metaphysical Issue}

In an earlier article, I demonstrated the necessary ingredients of metaphysics in education ${ }^{1}$. I propose now to show how Reductionism, sometimes called 'Reductivism', is a metaphysical issue, has serious consequences for human life, and can gravely affect educational practice and theory. ${ }^{2}$

Firstly, we need to distinguish Reductionism from the reduction of one set of laws to another within the same science, whereby the former set are shown to be special cases of the latter. Such reductions are legitimate simplifications. Reductionism, in contrast, is to be understood as the claim that one whole set of things is or can be wholly explained in terms of another set. It is, therefore, a reduction in the number of types of entity or the regions of the world. In particular, Reductionism today operates with a stratified conception of the universe--for example, mind, life, matter or energy--and claims to be able to eliminate the higher levels or to explain them completely in terms of the lower. Familiar examples are the claims that mind is observable behaviour and that people's beliefs and attitudes can be entirely explained in terms of their upbringing or social class. Reductionism, therefore, is to be understood as the claim that a given set of things are either illusory or epiphenomenal: they have either no reality or no independent power.

Three types of Reductionism have been distinguished ${ }^{3}$ :

a. Methodological--breaking down presently unintelligible wholes into their component parts, which can be managed, finding their structures and functions, and working thence back to an understanding of the whole. This is Reductionist, as the term will be used in this essay, only when it is assumed that the whole is 'nothing but' a collection of separable parts, and that is an ontological assumption. Otherwise it is a temporary legitimate practice which is followed by a re-integration of the parts into the reconstituted whole and a study of their joint functioning.

b. Epistemological--that the conceptions, theories and laws of one branch of science can account for and explain, without remainder, all the phenomena and processes studied by another, which therefore is denied any distinctive conceptions, theories and laws of its own. This is Reductionism in the relevant sense and makes sense only on the ontological assumption that the sphere or level of Reality of the chosen science is the only or only effective one.

c. Ontological--that one level of reality is nothing but another and lower one, or that all events and processes upon it can be accounted for by reference to those of the latter, which they are of which they are wholly the effects. Ontological Reductionism is presupposed by Epistemological Reductionism and by Methodological Reductionism when it is Reductionism as defined above.

We see this in 'Scientism', the belief that the methods of natural science, and especially of chemistry and physics, alone produce genuine knowledge. For only if all aspects of Reality are amenable to observation, measurement, experiment, and the like, and have no features which escape such methods, can it make sense to insist on them in all studies and to deny the validity of any others. 
Scientism is a form of epistemological Reductionism which thereby presupposes an ontological Reductionism, and a very radical one at that. Ultimately, the only, or only effective, reality is matter in motion, or energy, or whatever is taken to be the basic constituent of the universe.

Before we can survey the effects of Reductionism upon education, we need to specify further what it is and what its general effects are. We can see what it is by looking briefly at its origins.

\section{The Origins of Reductionism}

Reductionism arose with modern science, with which it has been closely associated ever since, so much so, that frequently opponents of it, as well as proponents, assume that natural science is inherently Reductionist. Yet it is important that we try to distinguish the new methodology which is modern science from specific interpretations given to it, so as not to foreclose the question of any necessary connection between science and Reductionism.

The most significant feature of the new science is its mathematical and mechanical conception of Nature. Burtt found this in Kepler's assumptions: 'The real world is a world of quantitative characteristics only; its differences are differences of number alone'4 . Much attention has been focused on Galileo and on this passage from The Assayer:

Philosophy is written in this great book, the universe, which stands continually open to our gaze. But the book cannot be understood unless one first learns to comprehend the language and read the letters in which it is composed. It is written in the language of mathematics, and its characters are triangles, circles, and other geometric figures without which it is humanly impossible to understand a single word of it; without these, one wanders about in a dark labyrinth. ${ }^{5}$

Let us note, with Grene, what is implied in this passage. Firstly, we have to leam the language in which the Book of Nature is written; that is, it is not a first language, not something which we acquire in daily life. Moreover, its script is also foreign, like Arabic or Chinese to Europeans. It follows that we have no pre-scientific--that is, pre-mathematical--knowledge of Nature, nor can we have any. Consequently, what we assume that we know about the universe, before we begin natural science, has to be set aside entirely. Secondly, it implies that mathematically, is real. And that means that the universe consists of matter in motion, and no more, all else being taken to be a function of matter and motion.

We can see this consequence explicitly expressed in another conception from Kepler and Galileo: the revived Democritean distinction between primary and secondary qualities. The former are shape, size, place, motion or rest, contact or lack of contact with other bodies, and number, and cannot be separated from the idea of a body or substance. The latter are colour, taste, sound and smell, which are not entailed by the idea of a body, and

are no more than mere names so far as the object in which we place them is concerned, and...reside only in the consciousness. Hence if the living creatures were removed, all these qualities would be wiped away and annihilated. ${ }^{6}$

The primary qualities, which really exist in the object, are just those which can be treated mathematically: shape, relative size location, date, velocity, contiguity 
or distance, and quantity. Conversely, the secondary qualities, which are alleged not to be real and not in the object itself but mistakenly located there by us, are just those which are unmeasurable: colour, taste, sound, and smell. These, with exceptions of intervals of pitch and degrees of intensity of sound, are pure qualities. Thus, they are denied any place in the universe save as merely subjective experiences. And a merely mathematical science would deal with them only as, or as functions of, matter in motion, or mass, and energy; that is, as or in terms of, waves of sound and light, and the chemical processes of taste and smell.

These assumptions are with us still, and show themselves in the pressure to quantify and measure and to ignore the qualitative aspects of things. Such procedures make sense only on assumptions such, that the universe is a realm of quantity and not quality, and thus of matter in motion, mass and energy, molecules and electrons, the objects of chemistry and physics. Hence, the epistemological Reductionism of assuming that all other studies can be replaced by physics and chemistry or are valid only as adopting their procedures.

\section{Its Wider Significance and Dangers}

Let us now consider some of the wider effects of Reductionist ways of thinking. We shall first look at effects it has had upon our conceptions of knowledge, values and language, and then at its effects upon the ways in which people actually conduct themselves.

Reductionism has three effects upon knowledge: (a) to require it to be quantified; (b) thus, to require it to be abstract and general; and (c) to require it to be 'objective' and 'impersonal'. Thus, it would conform to the paradigms of physics and chemistry which deal with what really or fundamentally exists.

(a) We return to Galileo's assertion that the Book of Nature is written in the language of mathematics which implies that we have no pre-scientific knowledge of the universe. Knowledge, we may generalise, is knowledge only insofar as it is precise, and, thus quantified. Thus, Thorndike's 'Whatever exists at all exists in some amount ${ }^{7}$ states concisely the ontological presuppositions of the widespread demand for precision and measurement. It is frequently assumed all knowledge should conform to that of the exact sciences in order to be knowledge and, so, it is presupposed that all Reality is like those aspects of it studied in physics and chemistry. Consequently, the validity of every-day knowledge or common sense or what Husserl called the 'life-world', the world of immediate perception and pre-scientific living, is denied: Our common knowledge of human nature is both vague and unsupported by adequate evidence and so really cannot count as knowledge. ${ }^{8}$ That is, I assume, its basis in our lived experience of ourselves and others is not adequate evidence which could come only in the form of scientific psychology based on quantified tests which would render it precise and not vague. It is relegated to the sphere of mere 'appearance' whereas Reality is found in the formulations of science. The table really is the physicist's pattern of atoms in a mostly empty space; despite our own beliefs, we are our overt behaviour (Behaviourism), our genes (the socio-biology of E.O. Wilson), the extentionless, intersections of social roles (as implied in much sociology). Despite what we say to the contrary, our religious, moral, and political beliefs are rationalizations of childhood insecurity (Freudianism) or ideological maskings of our economic interests (Marxism). In 
each case, the latter formulation is the 'objective' reality behind the subjective appearance.

(b) Moreover, scientific knowledge, as it is found in chemistry and physics, is abstract and generalising. It deals not with the individuality of the individual, which is beyond measurement and prediction, but with only the particular as an instance of a law, type, or formula. Hence, the ambitions of the social sciences to find and formulate laws in the human world and thus to make predictions from them. If all knowledge of human beings as in the last quotation is to conform to this pattern, then it is presupposed that in the human world what is individual and unique either does not exist or is not worth bothering about, and, so, in the latter case, is epiphenomenal in having no effects upon anything else. Consequently, history is to be turned into a social science like psychology and sociology, not studying the unique and particular which is either unreal or not scientifically knowable, but attempting to formulate general laws from which predictions can be made. ${ }^{9}$

(c) Finally, the radical Reductionism, which lies behind these demands, calls also for knowledge to be detached, impersonal and, 'objective' in the same way as it holds chemistry and physics to be. For, as Burtt and Polanyi have pointed out, ${ }^{10}$ the metaphysics erected upon the new science eliminated humans from the world and, thus, the scientist from his or her science. If the universe is only matter in motion or electrons and molecules, then the minds that know it have disappeared. With Descartes, the mind retreated to a comer of the brain and the world was divided into Thought and Extension. But, sooner or later, mind itself had to come under the scope of the new science, and so, it became the brain. And overt behaviour was studied in and by itself without being taken to be the external effect of an inner cause. If knowledge in some way depends upon the knower, and involves control, decisions, responsibility, and commitment on his or her part, then it is infected with 'subjectivism', the realm of the unreal. On the contrary, to be knowledge, it had to be a function wholly of the object, a mechanical duplication of the object and an automatic and impersonal process. Knowledge, thus, is knowledge of things and knowledge by things-e.g. marks on paper, pointings of dials, computer print-outs, photographs, all of which are simply there and, hence objective. Estimates, evaluations, and judgements are, therefore, 'subjective' and not knowledge, and so infect with 'subjectivity' and unreliability anything which they accompany.

In the new world-view, qualities are 'secondary' and do not inhere in the things themselves. Likewise, all values are projected upon them by us. Authentic science is 'value-free', and, as stated by Rickert and Weber, while human science may study people's beliefs about values, they themselves must not make evaluations. Evaluations are merely 'subjective' opinions, perhaps expressions of some ideology. Alternatively, they may be seen as group rather than individual projections, the Relativist thesis. Yet again, they may themselves be reduced to 'natural' facts (in the modern understanding of 'nature' and 'natural') and so be identified with merely natural qualities, reactions of pleasure, people's beliefs or what people do--the Naturalist thesis. Indeed, the general assumption is that they are either merely natural facts or creations by the individual or group. Thus, rejection of 'the Naturalistic Fallacy' results in acceptance of some form of subjectivism or relativism, which some moral theorists try to stabilize by appealing to formal principles such as universalisability. 
Finally, Reductionism affects the language we use. We have all heard injunctions to use 'objective' and to avoid 'emotive' language. A certain neutral, third-person, and expressionless style, with extensive use of abstract nouns (and adjectives and verbs formed from them) and the passive voice is now required in higher education. Evaluative utterances are 'merely emotive' expressions of one's own feelings or attempts to evoke feelings in others and, thus, to influence their conduct, and so, are unverifiable as cries of pain or words of command. ${ }^{11}$ Language is, therefore, said to have two fundamental uses: a symbolic or descriptive one for recording and communicating facts, and an emotive one to express or excite feelings and attitudes. The former is its scientific use in making statements which are true or false, whereas emotive utterances cannot be true or false. ${ }^{12}$ The world being a neutral realm of mere facts, statements about it must also be neutral and merely factual, and only thus can they refer at all to Reality and be true.

We shall now glance at the effects of Reductionism upon human life. I suggest that what is likely to happen, and has, in fact, happened, when Reductionism gets out into the streets, is a coarsening of human attitudes to themselves and each other. If we believe that we are 'nothing but' fulfillers of social roles, the products of our early conditioning, regularities of behaviour determined by environmental variables, our position in the economic structure and processes of production, 'naked apes', organisms, vehicles for the reproduction of genes, or our chemical and physical composition, then sooner or later we will be influenced by those beliefs and act upon them. Eventually we shall treat ourselves and our neighbours accordingly. If we hold that we are, as Skinner says, 'beyond freedom and dignity', then we shall not treat each other as free and worthy but as mere things to be manipulated as we think fit. If we believe that values are subjective projections upon a world neutral in itself, then we shall cease to sacrifice to them our comfort and desires for wealth and power. William's Trousered Apes ${ }^{13}$ and Holbrook's Education, Nihilism and Survival show in detail how such conceptions have affected literature and daily life.

\section{The Effects of Reductionism upon Education}

I shall now present some examples of ways in which Reductionism could manifest or has manifested itself in education. I make no claim to be exhaustive.

\section{a. On aims and objectives}

Statements of aims in education are usually innocuous and mean very little. What matters is how in detail they are interpreted, expanded, contracted, or ignored. The aims actually pursued usually need to be inferred from people's practice, and even in educational theory they have to be inferred from the whole body of the text and not just those passages where they are explicitly stated. Consequently, it is not easy to cite clear examples of the effects of the various Reductionisms upon aims in education, especially as no one group, for the most part, dominates any institution. It is the details of the curriculum, conceptions of childhood, conceptions of learning and knowledge, and methods from which enable us to infer effects upon aims. But a few examples can now be given and some suggestions made.

We may say that aims and objectives would logically be redefined in terms of the restricted conception of the world held by the Reductionism in question. Thus, on the assumption that the world is a collection of neutral facts, 
there would be silence about any transmission of values and mentions only of facts and techniques, which, of necessity, would be arbitrarily selected. Again, with a Behaviourist view of human beings, education is seen in terms of shaping behaviour and never in terms of developing an inner self of thoughts, feelings, and imagination, except as these are redefined in terms of overt and specifiable behaviour. Nor can a being who is overt behaviour be credited with selftranscending ideals and, thus, a need to have them aroused within him. Hence Professor Skinner's view of education: "Education is the establishing of behaviour which will be of advantage to the individual and to others at some future time"14. He goes on to make it clear that it is the others who condition the individual to serve their ends for all human motives are self-serving.

I suggest that Reductionist views of education, to the extent that, like Behaviourism, they are 'scientific', will put an emphasis upon specifiable, observable, measurable, and, thus, 'behavioural' outcomes ('terminal behaviour') and wider, less determinate and tangible results at which one aims, or for which one hopes, will be dismissed as unreal. ${ }^{15}$ Some readers will doubtless be familiar with demands to specify objectives in 'behavioural terms'. But how can one specify the 'terminal behaviour' that is an adequate understanding of and response to "On Westminister Bridge" Indeed, how can one specify it in any terms?

\section{b. On the curriculum}

A consistently applied Reductivism would eliminate from any curriculum those subjects which deal with those levels of Reality which it denies. Yet, because institutions usually encompass more than one view, what in fact happens is that the customary subjects continue to be taught but teachers and lecturers of a Reductionist outlook interpret what they teach according to their views of it. Thus, we find biologists given to radical Reductionism still teaching biology as a separate subject, and not chemistry and physics, yet maintaining that it is really nothing more than physics and chemistry and that it uses only the conceptions and methods of those two sciences.

Within subjects less radical forms of Reductionism show themselves in the elimination or reinterpretation of the higher levels of each subject. And so, for both these reasons, we may see no effect upon the curriculum as a collection of subjects and activities, but shall see it in the details of what is taught within its components. Let us now look at some examples.

In relation to the curriculum of the school, we shall have to look more to the incidental comments of individual teachers, for text-books are written to be used by persons of different outlooks and approaches. Reductionism will, therefore, manifest itself more in what the teacher says about his subject and in what aspects he or she emphasises, ignores, or reinterprets. For example, a Marxist teacher of history will emphasise the economic system of the period and the social system as supposedly arising from it, and will explain all other events by reference to them. Such a teacher will teach that political and religious beliefs are ideologies, weapons in the struggle for economic and social dominance, with no inherent truth and power of their own. Perhaps this will not be stated explicitly, but it will be implied. More openly, Marxist accounts of history and society are to be found in further and higher education, and in the books written for use there. In higher education, there is also the positivism in political and legal studies which regards only questions of fact as legitimate, and, thus, 
eliminates any constructive political or legal philosophy which would raise and attempt to answer questions about the value and legitimacy of institutions and laws. In political studies, there is also a widespread reduction of motives to desires for power and wealth only, as in interpretations of events in terms of interest groups alone.

A clear example of the effects of Reductionism within a subject at the level of the school is sex education. One general effect of Reductionism is the elimination of value from the world which is then interpreted 'objectively' as a realm of bare and neutral facts. On this basis, all subjects should be taught in a merely factual way, as bodies of information and sets of manipulative skills, and not also as matters of values which are to be appreciated, admired, and cherished. Education, thus, becomes a matter of imparting only knowledge about things and of developing only techniques of manipulating them, of the head and the hand and never the heart. What we find in many schemes of sex education today is the teaching of only the 'objective' and, thus, physiological and sociological, facts and techniques of reproduction, intercourse, other sexual practices and contraception. Human sexual life is, thus, reduced to its purely physiological basis and its motives to that of self-gratification.

The Reductionist division of language into a purely descriptive reporting and communication of facts (neutral facts) and a purely 'emotive' expression or evoking of mere feelings, has affected the teaching of language in schools. Lewis began his The Abolition of Man with some quotations from two textbooks of the time which took over this dichotomy and applied it to the teaching of English. ${ }^{16}$ (I have seen similar accounts of language given in more recent text books and have heard them expressed by teachers and the trainers of teachers.) Epithets such as 'sublime' were therein said not to describe things in the world, such as waterfalls, but only to be about the feelings of the speaker, with the implication that, thus, they are not really important. In the same works, this leads to a generally debunking and negatively critical approach to language: all that is not neutrally factual becomes suspect. Hence, the stock exercise of analysing the manipulative techniques of advertising. Of course, much advertising is like that, but it is implied in much of English today, just as it was when Lewis wrote, that all persuasion is and must be like that. What used to be taught under the heading of Rhetoric, eloquent and persuasive wisdom, is now seen merely as manipulation of language and one's audience to suit one's ulterior purposes. Since there are no values in things themselves to which our emotions and attitudes can rightly respond and be attuned, expressions of emotion and attitude cannot be true nor false. So children are to be taught an expressionless way of writing merely factual accounts, an explicitly 'subjective' mode of selfexpression which is no more than the outpouring of wholly internal feelings with no external counter-parts, a view of poetry as being the same sort of thing, and a suspicious and destructive analysis of others' language when it is not neutrally descriptive. Professor Bantock has shown how the rhetorical education provided by Renaissance humanists gave way in the seventeenth century, as a result partly of the new science and Reductionist interpretation given to it, to a more simplified and plain style of writing and, thus, of thinking in which poetic language was seen as omamentation only. ${ }^{17}$ What we see today is a more extensive approach to language and the teaching of it.

Reductionism in the teaching of literature will show itself in the general 
run of books chosen and their reduced, debased and debunking view of man, as Holbrook has demonstrated.

One effect of a Reductionist denial of the reality of value in a merely factual universe is to arouse an avowedly subjectivist reaction which openly proclaims the absence of genuine values and thence standards for its beliefs and activities. This attitude has permeated the teaching of art in some schools and colleges in which no attempt is made to inculcate values and standards and where unlimited and undirected self-expression is allowed and encouraged. Of course, Reductionism is not the only cause of this attitude. There is also at work the Romantic idea of the untaught genius now extended to any self-proclaimed artist, and the resentment at having to work, to acquire skill and craftsmanship, and to be criticised. Yet, we can plausibly suggest that Reductionism, in generally discrediting values and standards, certainly reinforces this attitude even though it may not have created it.

Though, it may not yet have not happened, we can suggest ways in which Reductionism, in its denial of values and standards, could affect the curriculum in craft, design, and technology. A really consistent, and radical Reductionism would reinterpret technology as no more than physics and chemistry and would deny that it has a level of its own--of efficiency and effectiveness--which is not to be found in inanimate Nature untouched by man or animals. ${ }^{18}$ But to eliminate that level and these conceptions and standards would be to destroy technology. Yet, what could be done would be to reduce craft and design to technology alone, to efficient and effective means to given ends, and to ignore the other and aesthetic dimensions of good design and good craftsmanship as 'merely subjective' projections upon neutral facts. One sometimes suspects that this has happened in the teaching and practice of architecture.

There have been complaints that medicine has been reduced to a mere technology of the body on the apparent premise, common to Cartesianism and Behaviourism, that the human body is just a mechanism--what in German is called Korper as opposed to Leib or lived body, the body as experienced by the person himself. In reaction, many people have shown an interest in unorthodox, alternative and holistic varieties of medicine. And, recently, some leaders of the medicinal profession have called for more attention in the teaching of medicine to the preparation of doctors for dealing with patients as persons. In any case, we can imagine what would happen if such a reduction of the patient to a bodily mechanism alone were to influence the teaching of medicine: its curriculum would consist only of the technology of drugs and surgery and the study of anatomy and physiology, with no mention of what all this means to patients themselves and no training in approaching them as persons and as individuals who are not merely 'cases'.

And we can also imagine how Reductionism could similarly affect the teaching of sports and games and could reinforce other tendencies to approach it only as the transmission of skill, technique and the ability to win, to the neglect of inculcating sportsmanship, respect for the game and one's opponent, and observance of its rules upon all occasions, all of which would be treated as merely 'subjective' attitudes fit only to be debunked.

Finally, in this section, let us consider a proposal for the curriculum of the school which is explicitly intended to be non-Reductionist; Professor Hirst's account of his seven or eight forms of knowledge. He implies that they are to be 
the centre and culmination of the curriculum, though they may be taught through fields of knowledge which combine more than one form. He insists on their logical distinctiveness and the impossibility of reducing any one to any others. ${ }^{19}$ But in another way there is a definite tendency towards Reductionism, certainly in its more radical and 'scientific' forms: viz, its denial of any pre-scientific knowledge. That is just what we find in some passages in Hirst's account, although there are others which point the other way. Thus he states that knowledge is not just the tested and public statements in which it is expressed but also the experience which is structured by the forms and therefore expressed in that way (KAC, p. 40); that not all knowledge can be stated (KAC, p. 45); and that the distinct forms of knowledge are rooted in and feed back into the common world of persons and things $(K A C, p .52)$. Yet in contrast he also states that all knowledge is 'fully propositionalisible' (sic) 'in principle at any rate' ( $K A C$, p. 86); that common sense knowledge has nothing distinctive of its own but is simply those elements of knowledge from the forms which are taken for granted in a given society $(K A C$, p. 90$)$; and that all knowledge of empirical fact, and thus large parts of psychology, sociology and history, are 'of the strictly physical science variety' $(K A C, \mathrm{p} .86){ }^{20}$ These latter remarks, all from a later essay, suggest respectively that all knowledge is explicit, that it is scientific in the wider sense of being a disciplined and organised body or capable of being included in such, and that all knowledge of facts, other than of human intentions, is knowledge of what is observable and thus of what is studied in physics, It is to be noted that nowhere does he consider that biological and technological sciences may have conceptions and methods which separate them from physics and chemistry. This neglect and that last explicit remark imply a reduction of biology and technological sciences to chemistry and physics. But more than that, all three of these remarks suggest a tendency to assimilate all knowledge to its scientific forms and away from that form which it takes in the life-world, similar to what was implied in Galileo's statements about the Book of Nature being written in the language of mathematics.

Let us then imagine the results if we were consistently to follow this latter tendency in Hirst's thinking and, therefore, to deny outright the pre-scientific knowledge of the life-world in favour of the explicit, tested, precise, generalising, and abstract knowledge of science. Out would go history from the curriculum, since that employs nothing that is not to be found in our everyday living, but employs it more disinterestedly, for its own sake, systematically, and upon sources which ordinarily we might not have thought of, such as materials in archives. ${ }^{21}$ Likewise out would go literary and artistic studies which also employ nothing or little more than our everyday abilities and conceptions. All that the child brings with him or her would be discounted on principle as pertaining merely to surface appearances and not the hidden Reality knowable only through scientific approaches. Thus, what we ordinarily know about our status, situations, and roles in social life would have to be replaced by an abstract, generalising, and 'objective' sociology whose conceptions would not be those of everyday existence. Similarly, our everyday knowledge of persons, ourselves and others, how they think and act, and how to understand them, would be replaced by a scientific psychology and its own technical terminology. Again, out would go our ordinary knowledge of Nature. Now there was indeed little that was veridical in pre-scientific beliefs about the subject-matters of 
astronomy, chemistry, and physics, but that was certainly not true of men's knowledge of animate Nature gained in many centuries of intimate contact with it as hunters, herders, and growers. There were many false beliefs about living things, but equally there was much genuine acquaintance with them. And likewise, as Polanyi remarked, ${ }^{22}$ there is much practical knowledge in arts, crafts, and industries which a scientific approach has first to recover and assimilate in its own explicit and analytic manner before it can discover anything new on its own account. But also such practical knowledge would be discounted. And generally, whether this were explicitly taught or not, the pupil would come to discredit everything that had no pretensions to be scientific.

\section{c. On Conceptions of learning and methods}

For a Behaviourist account of these matters, we turn to Professor Skinner's Science and Human Behaviour, where education is explicitly said to proceed by means of conditioning and artificial reinforcers such as awards, grades and stars, or entry into jobs and controlling groups (p. 405). We note here the assumption that the pupil's only motivation is self-gratification to which his education is merely a means, though in speaking of 'progressive education' and its use at an earlier stage of 'non-educational reinforcers', Skinner does recognise to some extent the possibility of intrinsic satisfactions in 'non-educational reinforcers' such as the use of a foreign language to read its literature (p. 406). Knowledge is reduced to the behaviour with which we react successfully to the world (p. 409); the 'verbal knowledge', which education mostly imparts, is reduced to the ability to restate the words on suitable occasions; while understanding, as of a text in history, is reduced to the probability of emitting verbal responses similar to those of the text. ${ }^{23}$

We noted above that a more general effect of Reductionism is the demand for specific, measurable and, hence, behavioural objectives. Such a demand affects in turn the content and the methods of education. For the content itself has to be specified in detail and, thus, broken up into discrete items, corresponding to the specific objectives, and the method must rely heavily upon testing the attainment of those objectives. Larger and less determinate aims are not specifiable in detail, nor measurable, nor at all statable in behavioural terms, and with their elimination will also go out larger and less determinate contents. For example, in the teaching of poetry, the poem itself will have to be broken down into a number of discrete and repeatable items, the reproduction of which will count as understanding the poem, with nothing remaining. Likewise, skills will be broken down into discrete and repeatable movements, whose performance can be measured. In general, what will be taught and the methods used for teaching it will be determined by the demand to specify and measure it and to measure it precisely and 'objectively'.

Reductionism, in its more radical forms, would reduce knowing to a function of the object alone, and, thus, view as 'subjective' any contribution and involvement of the knower. This is what Polanyi called 'Objectivism' and argued against throughout Personal Knowledge. The literature on measurement and evaluation in education, at least that coming from America, is pervaded by this attitude, and, despite a few gestures towards qualitative assessment, takes for granted the demand for precise and, thus, quantitative measurements and statistical computations of them. Only thus, it is assumed, can 'objectivity' be achieved. 'Objectivity' is defined, in effect, as the impersonal making and 
computation of measurements, with which evaluation is identified or upon which is taken to be a second and less 'objective' stage of assessment. Thus, 'an evaluation is subjective to the extent that it depends on who is evaluating rather than on what is being evaluated', and the extent to which a measurement or evaluation is 'subjective' is 'the degree to which personal bias and prejudice can influence scores. ${ }^{24}$ Let us examine the assumptions in this paradigmatic statement of Objectivism:

(i) The former assertion allows any expertise and connoisseurship in judgment, any superiority of one person's judgment over another, so that one's judgments and decisions are better because they are one's own. That would only show that they are infected by 'subjectivity'. The connoisseur's judgment of a wine, the critic's judgment of a painting and the referee's judgment of a scientific paper are then 'subjective' because they depend upon who are making them, just as does that of someone totally ignorant of wine, art, or science. Consequently, if education is dominated by the demand for 'objectivity', and, thus, for impersonal measurement, it cannot in any way aim at training judgment, expertise, and connoisseurship. Such matters cannot count as knowledge.

(ii) The latter assertion identifies the personal ingredients of judgment and decision with prejudice and bias, for it does not say 'subjectivity' is the degree to which prejudice and bias do influence scores but that it is that to which they can influence them. Now if they can influence scores, so too can skill, expertise and connoisseurship, and, if some supposedly impersonal and hence mechanical means of measurement eliminates the possibility of the former, it also eliminates the need for the latter. ${ }^{25}$ What is then sought in education is such means of measurement as need the minimum amount of judgment on the part of the measurers.

(iii) And the latter assertion also assumes that evaluation is a matter of measurement, of scoring, of quantities only and never of qualities, so that in education, if it cannot be given numerical scores, then it cannot be assessed and cannot be taught.

Let us now examine the consequences of such attitudes. One consequence is the use of 'objective' tests. Now why should tests, which use the technique of giving a choice of answers and requiring the person being tested to tick or circle or underline one of them, be called 'objective' tests and not just 'multiplechoice' tests? The answer can be only that it is assumed that they reduce the need for judgment on the part of the marker. But this is quite false.

While the marking appears to be mechanical, and may be done with a screen which blanks out all the wrong choices or by a computer, it still calls for the marker, or punch-card operator, to decide which, if either, of two ticks, one apparently crossed and the other not, is to count, or whether a smudge is really a shading. More importantly, it is still marking, judging which are the correct answers. The marker commits himself to the general validity of the test and to the correctness of each answer so designated on the marking scheme or in the computer's program. But the test may not be a valid one in the first place and a particular answer designated as correct may be incorrect. For example, I once administered a paper on 'The Use of English'. I had a go at it myself, and was able correctly to answer most of the comprehension question, set as a multiple choice, without having to read the original passage at all. It tested my ability to guess based on general knowledge, but in no way at all was it a valid test of my 
ability to understand the passage set. Likewise in mathematics, in and by themselves such tests test only the ability to guess correct answers and never any understanding of mathematical methods. Hence, they penalise the person who uses an appropriate method and makes a slip in calculation yet reward the person who happens merely to guess the correct answer. And for a particular case, I shall quote an example from a text-book for English: 'Which is the odd one out? -- equine, feline, vulpine, canine'. Now I do not know what the compiler had in mind as the correct answer, and am at a loss to guess it. I could suggest 'canine' on the grounds that it refers to a type of tooth found in animals other than those to which the adjective primarily refers. Whatever might have been intended as 'the correct answer', and thus given to a marker if this had appeared on a test, any marker has to use his personal judgement in deciding whether to allow the other possibilities or not. The same goes for questions which ask for a 'best answer': the marking scheme still designates only one and it may not be unambiguously the best nor even the best at all. Yet again with marking schemes that give a scale of marks for the options: the one given the most marks may not be the most appropriate. The compiler had to use his 'subjective' judgment in setting up the test, and the administrator and marker have to use theirs in deciding to use and stand by it, its validity and its marking scheme.

What happens if and when such tests become the rule? All that is tested, and, thus, all that is taught and learned is the memory, guessing, and reproduction of specific items, to which knowing and education are thereby reduced. Let us compare them with traditional essays in literary subjects. They can be marked in the same way for specific items only, as one does at the lower levels of secondary schools, and, in Nigeria where rote memorisation and reproduction is everyone's idea of education. That is how, with regret, I had to mark essays and examinations at a College of Education. But the essay can be used and marked for skill in selecting what is relevant, in showing that it is relevant by appropriately using it, in marshalling the selected material, and in developing approaches and ideas beyond what is usually expected at that level. Now all these are matters of judgement on the part of writer and marker, and cannot be assessed by any 'objective', pre-determined and tight marking scheme. Indeed, any such scheme must penalise constructive originality just as much plain irrelevance, for logically it cannot accommodate what its compiler has himself not foreseen as a valid interpretation, approach, or answer. Likewise, the project or collection of work in CDI and Art permits and calls for some originality on the part of the candidate, and so requires personal judgement by the assessor of the degree and quality of originality shown. Again, in mathematics, traditional problems can be marked for understanding and selection of methods in addition to, and perhaps more than, calculation of the correct result, and require the marker personally to read the working and not just the result, and to judge the appropriateness of the methods selected.

If only the measurable is real, then none of these qualities and abilities can be assessed, and, thus, developed, in education, but only those limited techniques, and sheer guessing, required for obtaining scores on 'objective' tests. (But whose 'subjective', judgment decides what is a good or bad score on such a test? And there is no point in any test unless we give some meaning to its results.) 


\section{d. On the training of teachers and administration of education}

Obviously all the above effects could appear also in the training of teachers: the aims could be lessened to those things held to be real, so that the higher levels of themselves and their pupils would never be mentioned nor seen as aspects to be developed; the curriculum would thus be restricted to those lower levels; and they would be taught Reductionist theories of human nature and knowledge, and corresponding notions of aims, objectives, methods, and assessment. And one need only glance at some books of educational psychology, sociology of education, and measurement and evaluation to see that something like this has happened.

Yes, and philosophy of education also. For it, too, has suffered from Reductionism, as can be seen in the manifest Positivism of Professor O'Connor's book, and more widely in the domination of the subject, from about 1965 onwards by Linguistic and Conceptual Analysis which reduced philosophy to 'talk about talk', because it implicitly upheld the Positivist theses that Reality is only what is empirical and factual (and that is a form of Reductionism), and, thus, that all knowledge is contained in the special sciences, and so could not think of anything else for philosophy to do.

Within philosophy of education there has been a debate, between Professor O'Connor and Hirst about the nature of the theory of education which, of course, is to be taught to teachers in training. On the one side, O'Connor maintained that the only elements which could qualify as theory were those from sociology and psychology, that is, the factual and descriptive ones. On the other hand, Hirst maintained that a prescriptive element must also be included. ${ }^{26}$ Thus, O'Connor in effect presents a Reductionist vision of the world, or the knowable world, as a merely factual one and accounted for by natural and social sciences, whereas Hirst in effect invites us not to be restricted by such an ontology and epistemology. If we were to follow O'Connor, educational theory, and what is presented to teachers, would consist only of generalising theories about what is the case, and explicit maxims of technique based upon them. As for what teachers ought to do, that could be decided, as was noted above, only by either a totally arbitrary decision on one's own part or by sheer conformity with the prevailing fashion--i.e. Subjectivism or Relativism. Yet in the same place (p. 73), Hirst, as Degenhardt notes with quotations from Skinner to the same effect, ${ }^{27}$ could dismiss as 'folklore' the pre-scientific knowledge which has guided practice to date and now should be abandoned. ${ }^{28}$ We noted above something similar from O'Connor on the vagueness and untrustworthiness of our ordinary knowledge of our fellows. If we were to follow these dismissals of the life-world, the experience that teachers bring with them to in-service courses, and which teachers in training gain in teaching-practice, would be discounted at the start, except as it coincided with what is to be found in an abstract, generalising, and quantitative psychology and sociology. And generally, a Reductionist view of educational theory and the training of teachers would discount philosophical and literary approaches in favour of 'scientific' ones.

Finally, Reductionism could affect the administration of education in similar ways, and especially in a demand for hard and quantified data, and the ignoring of everything else, on which to base decisions. That would result in a neglect of the quality of education, of what is taught and how deeply or super- 
ficially it is taught and assimilated, and in concentration upon quantities of teaching--numbers of teachers, pupils and schools; hours spent on courses; the number of pages read; years spent in educational institutions; money expended; square feet occupied; the number of times a paper is cited by other writers. Goodlad cites his own experience of administrative reductionism and proposes a scheme for assessing quality in teaching. ${ }^{29}$ Yet, that proposal for compiling a file of documents relevant to one's teaching could itself lead to just the sort of thing he wishes to escape. For the proposed file of documents could take over from one's teaching, so that one does what can be recorded in the file and neglects that which cannot, irrespective of its genuine importance or insignificance.

Given that Reductionism does or would have these effects upon education, and that they are undesirable, what then is to be done? I suggest that this question is to be answered on four levels:

1. We need to make a definite effort at a non-Reductionist and even an anti-Reductionist education in order to combat and, perhaps, forestall those wider and serious effects upon life generally to which Williams and Holbrook have drawn our attention. I suggest that in schools this would mostly be a matter of incidental remarks as the need arises to counter what pupils say or what appears in text-books and the like.

2. We also need a survey of text-books, examination syllabi, and papers, lecture-courses and the like in order to discover any signs of Reductionism in them, both explicit and implicit, such as the omission of higher levels of life and persons or non-quantitative assessments.

3. In support of the above we need a survey of academic disciplines and of the other activities that form the curriculum in order to show that they are not 'nothing but....', and that they have aspects, laws, conceptions, and the like which cannot be accounted for, restated, or explained in terms of any lower levels. With this we need historical and critical surveys of Reductionism. ${ }^{30}$

4. We also have the constructive task of articulating, or taking over, an ontology and then an epistemology which allow for a stratified world and can explain how its levels are interrelated. ${ }^{31}$ 


\section{Notes}

${ }^{1}$ See my "Metaphysics in education," Journal of Philosophy of Education, 23(2), 1989.

${ }^{2}$ Others who have made a start on this study include A. Peacocke, (Ed.), Reductionism in Academic Disciplines (Guildford: SRHE \& NFER Nelson, 1985); M.B. Degenhardt, "Educational research as a source of educational harm," Culture, Education and Society, 38(3), 1984; D. Holbrook, Education. Nihilism and Survival (London: Darton, Longman and Todd, 1977) and Education and Philosophical Anthropology (London: Associated University Presses, 1987). 1 intend to take it further.

3. Peacocke, "The case for Reductionism in the sciences," A. Peacocke (Ed.), op. cit.

${ }^{4}$ E.A. Burtt, The Metaphysical Foundations of Modern Science (London: Routledge, 2nd ed., 1964), 56.

${ }^{5}$ Quoted in M. Grene in Approaches to a Philosophical Biology (New York: Basic Books, 1968), 10. The following remarks are based on Dr. Grene's comments, 10-14); see also Burtt, op. cit., 64, and on Kepler, 56.

${ }^{6}$ Quoted in Grene, op. cit., 14; see Burtt, op. cit., 75-6, 78. harm," 234.

${ }^{7}$ Quoted in Degenhardt, "Educational research as a source of educational

${ }^{8} \mathrm{DJ}$. O'Connor, Introduction to Philosophy of Education (London, Routledge, 1957), 100.

${ }^{9}$ See the controversies about this collected in W. Dray (Ed.), Philosophical Analysis and History (New York: Harper and Row, 1966).

10 Burth, op. cit., 29; Polanyi, Personal Knowledge (London: Routledge, 1958), 142.

${ }^{11}$ See AJ. Ayer, Language, Truth and Logic (London: Gollancz, 1936), Chap. VI, and C.I. Stevenson, "Emotive meaning of ethical terms", Mind, NS XLVI, 1937.

${ }^{12}$ C.K. Ogden and I.A. Richards, The Meaning of Meaning (London: Routledge, 10th ed., 1949), 149-50.

${ }_{13}^{13}$ D. Williams, Trousered Apes (Enfield: Churchill Press, 1971).

${ }^{14}$ Science and Human Behaviour (New York: Free Press, 1953), 402. See also the associationist psychology of the 18th century and its impact on education in Priestley, found in G.H. Bantock's Studies in the History of Educational Thought (London: Allen and Unwin, 1984), Vol. II. Vol. I focuses on the consequences in educational theory in the 17th and 18th centuries of the change in the conception of Nature resulting from the new physics of Kepler, Galileo, and Newton, with its Reductionist interpretation.

${ }^{15}$ See the examples cited by Degenhardt, op. cit., 239-40.

${ }^{16}$ C.S. Lewis, The Abolition of Man (Glasgow: Collins, pbk ed., 1978), 7-14. Details of the two books are given in R. Lancelyn Green and W. Hooper, C.S. Lewis: A Biography (Glasgow: Collins, pbk. ed., 1978).

${ }^{17}$ Op. cit., Vol. I, especially 157.

${ }^{18}$ On this, see Polanyi, op. cit., 88-9.

${ }^{19}$ Knowledge and the Curriculum (London: Routledge, 1974), 84. Other references will be given in the text using ' $K A C$ '.

${ }^{20}$ This last point is echoed by A. Brent, Philosophical Foundations of the 
Curriculum (London: Allen and Unwin, 1978). See also below on Hirst's disparagement of 'folklore' in favour of science.

${ }^{21}$ Even B. Lonergan appears to disregard the intermediary position of history and literary studies as, on the one hand, disinterested and systematic (unlike everyday knowledge; compare this with legends), yet, on the other, employing nothing more than what is used in our everyday practice of reading what others mean, intend, and do. See his Insight (London: Darton, Longman and Todd, 2nd. ed., 1983), 175-9.

${ }_{22}$ Op. cit., 52.

${ }^{23}$ Skinner refers to Chapter XVI, 'Thinking' and to his Verbal Behaviour (New York: Century-Appleton-Crofts, 1957) for fuller attempts to specify such occasions and sets of actions (movements). Likewise, Ryle tried to give lists of sets of actions for mental terms. But all such attempts are what Polanyi called 'pseudo-substitutions', for they depend upon tacit and non-behaviourist awareness of knowing, understanding, and the like, by means of which such lists are compiled and interpreted. And, of course, they are never completed.

${ }^{24}$ See their articles, "The nature and scope of educational theory" in G. Langford and D.J. O'Connor (Eds.), New Essays in the Philosophy of Education (London: Routledge, 1973).

${ }^{25}$ This is, of course, impossible. See Polanyi's comments upon the use of cameras for judging races and of calculating machines, op. cit., 20n. and 93n.

${ }^{26}$ See their articles "The nature and scope of educational theory" in G. Langford and D.J. O'Connor (Eds.), New Essays in the Philosophy of Education (London: Routledge, 1973).

${ }^{27}$ Op. cit., 246-7 quoting Skinner's Beyond Freedom and Dignity (New York: Bantam Books, 1972), 19, 160.

${ }^{28}$ See also the comments of R. Downie, A. Loudfoot, and E. Telfer, Education and Personal Relations (London: Methuen, 1974), 93 on what Hirst and Peters say in The Logic of Education (London: Routledge, 1970), 51, about 'the socially developed person who can distance himself a bit from social facts and his fellows and theorize them' and so see the foibles of his friends 'in terms of some derivative of Freudianism' (viz., that this is to see people as types and not as individuals).

29" The sociology of reductionism: Administrative reductionism" in A. Peacocke (Ed.), op. cit.

${ }^{30}$ Critical reviews of Reductionism are to be found in the books already cited by Burtt, Grene, Lonergan, and Polanyi. See also M. Grene (Ed.), The Anatomy of Knowledge (Amherst: University of Massachusetts Press, 1969); M. Grene, The Knower and the Known (London: Faber, 1966); E. Husserl, The Crisis of the European Sciences transated by D. Carr, (Evanston: Northwestern University Press, 1970); R. Nozick, Philosophical Explanations (Oxford: Clarendon Press, 1981).

${ }^{31}$ Two examples of such an ontology are those of Polanyi, op. cit. and The Tacit Dimension (London, Routledge, 1966), and N. Hartmann, translated by R.C. Kuhn, New Ways of Ontology (Chicago: Henry Regnery, 1953). 